\title{
THE PERCEPTION OF DIETARY SUPPLEMENTS AMONG CONSUMERS ENGAGED IN SPORTS ON A REGULAR BASIS
}

\author{
RÓBERT SÁNDOR SZÜCS, ZOLTÁN SZAKÁLYI
}

\begin{abstract}
Inaccurate perceptions about body image can be identified not only among physically inactive people, but also among those doing sports on a regular basis. Corporate marketing communication further increases these uncertainties and doubts, thus the former readily become actual consumers of dietary supplements. The results of our primary research $(n=737)$ describe the sports-related activities, attitudes, and segmentation of those regularly engaged in sports, including details about the dietary supplements market. Our results indicate that the group of people engaged in sports on a regular basis is far from homogeneous. As many as 56.4\% of them generally have a positive attitude towards dietary supplements, and constitute the potential consumers of this product range. Opinion leaders (coaches), reference groups, and word-of-mouth advertising (fellow sportspeople) were found to play the key role in the choice of dietary supplements.
\end{abstract}

KEYWORDS: people engaged in sports on a regular basis, attitude, consumer protection, dietary supplements

\section{INTRODUCTION}

The role of sport in the fight against gaining weight and obesity is unquestionable. Developed countries keep failing in their attempts to reduce the proportion of those who are overweight and obese due to physical inactivity, thus, quite understandably, much less attention is paid to those members of

\footnotetext{
1 Authors are affiliated to University of Debrecen, Institute of Marketing and Commerce e-mail: szucs.robert.sandor@econ.unideb.hu.The publication is supported by the EFOP-3.6.1-16-201600022 project. The project is co-financed by the European Union and the European Social Fund.
} 
society who consciously fight physical inactivity; i.e. those who engage in sports on a voluntary basis. Of the population of the European Union, 27.6\% do not engage in any kind of physical activity. The corresponding figure of 49.8\% measured in 2017 among the population of Hungary can be considered particularly unfavorable (EUROSTAT, 2019). With regard to leisure-time-based physical activity outside of work, research data produced by the European Health Interview Survey (ELEF) suggest that only one-third of the adult population of Hungary engage in any kind of sports-related activity at least on a weekly basis. People who do physical activity every day of the week account for only $4.5 \%$ of the adult population (CSO, 2015a) ${ }^{2}$. As recommended by the WHO in 2011, at least 150 minutes of moderate-intensity or 75 minutes of vigorous-intensity physical aerobic activity per week is necessary for the benefits of exercise to be realized. To achieve additional health benefits, this should be increased to 300 minutes of moderate-intensity exercise, and 150 of more intense activity. In a study completed in 2017, Keller and Dernóczy pointed out that only $36 \%$ of young people aged 15-29 did sports in addition to compulsory physical education lessons at school, and the popularity of competitive sports was declining among young people. In the previous 20 years, the proportion of individuals engaged in the latter had decreased by $12 \%$ to $5 \%$ (Keller-Dernóczy, 2017). The overall conclusion is that, according to a combined indicator calculated based on walking, cycling, and doing sports, only a small proportion of the Hungarian population engage in the recommended level of physical activity $(14.8 \%$ of men, and $10.2 \%$ of women).

In this study we describe the attitudes of those engaged in sports on a regular basis towards dietary supplements. In a study from 2017, Bauer et al. found that $19 \%$ of respondents aged 15-29 consumed some kind of vitamin product at least on a daily basis, while the proportion of those consuming other types of dietary supplements was 7\% (Bauer et al., 2017). According to Bíró et al. (2011), more than $25 \%$ of the Hungarian population consume dietary supplements, and every second individual in this group does so every day. Assessments of the related product range vary considerably in the literature. A study by Lugasi (2014) discusses the risks of consuming such supplementary products. Németh et al. (2016) examined consumer behavior in the dietary supplements market and identified four segments. The weakness of the study is the small sample size. Boros et. al. (2012) studied food-related consumer attitudes in the context

2 Older individuals show less engagement with sports. ELEF's detailed summaries demonstrate that $28.5 \%$ of men aged $15-34$, and $10 \%$ of men aged $35-64$ (a mean of $14.8 \%$ for men) engage in sporting activities in accordance with the recommendations of the WHO. The proportions for women are $20.2 \%$ and $8.2 \%$, respectively (with a mean of $10.2 \%$ ) (CSO, 2015b). 
of functional foods and food supplements. Gilbert (2000) focused on the effect of the communication of the product range on the target market, examining the attitudes and knowledge of respondents. Dwyer et. al. (2018) described the challenges and difficulties of regulating the related products. The consumption of dietary supplements is very popular among sportspersons ${ }^{3}$. Reasons for the consumption of different products vary (e.g. protein products, amino acids, isotonic drinks, 'weight control' formulas, etc.), but their effectiveness is disputed. According to Poulios et al. (2019), taking protein supplements is widespread among professional and amateur team sports athletes, accounting for a market of 5 billion USD in the USA alone. Despite being frequently consumed, the number of supplements that have been shown to positively affect health or performance is low. However, individuals in specific situations can require supplements (Kruseman, Gremeaux 2020). A paper by Lubowiecki-Vikuk et al. (2019) clearly summarizes the basic factors involved in the consumption of such products, including the social and marketing aspects. The authors state the following: In the USA, more than $60 \%$ of the adult, and in Australia more than $70 \%$ of the university population, use dietary supplements.

The use of various dietary supplements may be associated with the nature of postmodern society - with its passive lifestyles, excessive consumption, medicalization of the body, and pressure on individuals to maintain a healthy and attractive body. The marketing activities of the pharmaceutical industry are also a factor in the increase in dietary supplement use, despite known cases of poor-quality production processes and the contamination of some supplements with prohibited substances. Despite concerns of efficacy and safety, supplements are still used for the purpose of weight management. These supplements are advertised as requiring less effort than dieting and exercise, are associated with claims of effectiveness, and are often cheap and are commonly available. A study by Magkos and Yannakoulia (2003) draws attention to the following: the under-reporting of habitual energy intake is widespread among athletes, and its magnitude should be carefully addressed when interpreting the results of dietary assessments. Other issues specifically related to sportspersons that are often neglected include the adequacy of standard portion sizes, the frequency of snacking, fluid intake, supplement use, weight-control practices, and the seasonality of sporting activities and food consumption. The segmentation of sportspersons is not as precise as may be assumed. One thing is certain: a highly profitable industry complex has been built on a segment comprised of those who are active in terms of sports, who are targeted with a product

3 The word "sportsperson" in this article is used in the sense of "anyone engaging in sports activity on a regular basis." 
range the professional appraisal of which varies widely. The consumption of dietary supplements may be interesting in terms of consumer protection too for example, in the case of special segments (youth). Parezanovic (2016) draws attention to the fact that the use of dietary supplements among adolescents seems to be influenced by their belief that dietary supplements work. The media has contributed to stimulating the use of dietary supplements by spreading, for instance, the myth of the ideal body. During adolescence, a period when selfconfidence develops, many adolescents do anything they can to meet that goal. Moreover, dietary supplements are often sold in drugstores or gyms as over-thecounter products without advice from a pharmacist.

For the study described herein, the aim was not to adopt a position about the efficiency of dietary supplements or their effects in terms of helping individuals to reach particular goals; instead, we describe the attitudes of different segments of consumers who are engaged in sports on a regular basis towards dietary supplements.

\section{MATERIAL AND METHODOLOGY}

In the research, we assessed the attitudes of respondents concerning the issues discussed above, including the form of the sports-related activities they do, and their consumption habits related to dietary supplements. For the selection of the target group of our primary research a conscious sampling procedure was used. The target group consisted only of people who voluntarily engaged in sports on a regular basis - i.e., at least once a week. People who did compulsory sports-related activities (e.g. in physical education classes at school) were not included in the sample, even if they did such activities several times a week (e.g. four classes of physical education at school). However, respondents who did sports voluntarily (e.g. handball training, or jogging) beside compulsory physical education classes were not excluded from the sample. Data were collected by students at the University of Debrecen Szolnok Campus, who helped to fill in the questionnaire according to strictly predetermined criteria (e.g. proportion of men and women; age of respondents - over 14 years old -; targeting a wide range of sports activities and geographical location; sport defined as physical activity, so - for example e-sports are excluded, etc.). If respondents met the requirement of undertaking voluntary sports-related activity (the non-random part of our sampling), the selection process was extended using the snowball method to the circle of acquaintances of the interviewee. 
We involved the widest range of sports activities in our research. Starting from yoga, through riding, gymnastics, running, and martial arts, almost all sports were represented. Their classification suggested 21 types of sports activities. When asked about the type of exercise they do, $24.8 \%$ of respondents specified aerobic exercise, $47.7 \%$ anaerobic exercise, and $27.5 \%$ of them both aerobic and anaerobic exercise. The most popular sports among the respondents were as follows: weight training (34.5\%), running (29.4\%), ball games $(18.9 \%)$, cycling (15.9\%), swimming (9.9\%), calisthenics (8.8\%), martial arts $(6.0 \%)$, and aerobics (5.8\%). Among ball games, soccer was the most popular, at $8.1 \%$. We can state that our sample is very wide-ranging.

To examine attitudes, we conducted a questionnaire-based survey in paper format in Hungary, involving a sample of 737 people $(n=737)$. The survey was carried out in 15 counties. The greatest proportion of respondents in the sample were from Jász-Nagykun-Szolnok county (36.5\%), but respondents from other counties were also involved in the following proportions: Pest county (18.6\%), Bács-Kiskun county (14.0\%), Csongrád county (12.2\%), and Békés county $(6.1 \%)$. According to the type of settlement, the proportion of respondents in the sample was as follows: villages $13.8 \%$, towns $53.9 \%$, county towns $26.3 \%$, the capital city $6.0 \%$. As regards the financial situation of the respondent's family, $59.0 \%$ of respondents considered it to be average, while $28 \%$ slightly above average. The survey was conducted between 6 November 2019 and 13 December 2019. All age groups from 14 to 72 years of age were represented. The mean age of the sample was $30.2 \pm 11.7$ years, mode 20 years, median 27 years. The proportion of women in the sample was $47.5 \%$, and of men $52.5 \%$. The gender diversity of the sample conforms to that of the population engaged in sport-related activities. As regards educational attainment, the distribution was as follows: secondary school graduates $(42.4 \%)$ - representing the largest proportion of the sample, followed by higher education graduates $(37.5 \%)$, skilled workers $(7.9 \%)$, and respondents with a primary education $(10.7 \%)$. Of course, there is no national list that includes all the people who voluntarily engage in sports on a regular basis (i.e. at least once a week) so we cannot state that our research is representative. In our sample, there are more men than women, which accords with data from the Hungarian Central Statistical Office (CSO 2015a, CSO 2015b). The frequency distribution of our sample in terms of physique is extremely similar to the distribution of people who engage in sports activities in accordance with the recommendations of the WHO; i.e. our sample reflects the population defined and described by the WHO in terms of body shape. 
Table 1 BMI categories in our sample and in the WHO sample

\begin{tabular}{cccccc}
\hline & Underweight & Normal & Overweight & Obese & Total \\
\hline $\begin{array}{c}\text { BMI category of respondents in our } \\
\text { sample (n=737) }\end{array}$ & 3.9 & 55.0 & 30.7 & 10.4 & 100.0 \\
$\begin{array}{c}\text { Distribution of BMI of people } \\
\text { who engage in sports activities } \\
\text { in accordance with the }\end{array}$ & 5.6 & 56.1 & 28.6 & 9.7 & 100.0 \\
recommendations of the WHO & & & & & \\
\hline
\end{tabular}

Note: Authors' calculations according to CSO $2015 \mathrm{c}$

The questionnaire also contained questions about respondents' personal characteristics such as body weight and height, which were used to calculate BMI. Statistical methods were applied to process the data (mean, mode, median, standard deviation, Cramer's association evaluation, Kendall's coefficient of concordance, cross analyses, factor, K-means cluster analysis, discrimination analysis, etc.).

\section{RESULTS}

The frequency of doing sports, as measured by demographic characteristics in the sample, corresponds perfectly to the data provided by the Central Statistical Office. Participants in the survey do sports-related activities 3.4 times a week on average. The value of the mode and median is 3 . Of the respondents, $88.9 \%$ conformed to the WHO recommendation that muscle-strengthening activities should be performed on at least two days a week. These data confirm that we were able to reach the population who are currently active physically in terms of sports. The proportion of those doing sports at least five times a week is $20.9 \%$, while $13.5 \%$ of them do sports once a week. As concerns the frequency of exercise, among the demographic factors Cramer's association coefficient was highest for age (0.3). In the sample, the proportion of those who had been engaged in sports for more than five years was 57.3\%. As regards gender, men do sports 3.75 times a week on average, while women do so 3.12 times. Our research confirms that sport is still primarily a male privilege. For men, the proportion of those exercising only up to twice a week is $25.1 \%$, while for women this proportion is 39.4\%. Among male respondents, 25.1\% do competitive sports, while for women the rate is $16.3 \%$.

It is also important to assess the attitude respondents have towards sports. As many as $62.1 \%$ of respondents consider themselves to be "sportspeople." Among those exercising at least five times a week, this proportion is $85.6 \%$. In 
their case, having a highly positive attitude is a relevant factor. Additionally, $66.2 \%$ of respondents exercising 3-4 times a week consider themselves to be sportspeople. Among respondents exercising a maximum of twice a week, 37.9\% consider themselves sportspeople. In their case, some slight overconfidence may be noted, which is where the self-defense mechanism of the respondents can be observed. However, another even more serious problem is that $61.9 \%$ of those classified as overweight based on their BMI (calculated from their body weight and height) considered themselves to be sportspeople, and the proportion of respondents claiming the same in the obese category was $51.9 \%$. Both proportions exceed the $51.7 \%$ of slim-build respondents who consider themselves to be sportspeople. Consequently, questions may arise as to how realistically the respondents perceive their body build, and how this is related to social value judgement. Another factor that may also be considered influential is earlier childhood body build, which, burnt into memory, could affect the current body image of respondents. It should be noted that $64.8 \%$ of the respondents of medium build according to the BMI classification consider themselves sportspeople, which may be a good basis for a comparison of the values associated with the other categories mentioned above. Our study was also extended to assess respondents' perceptions of their muscularity: namely, we examined how developed respondents perceived their own muscles to be, and then how they thought other members of society assessed the degree of development of their muscles. A difference between these subjective and objective body images was detected with ca. $30 \%$ of respondents. The relationship between the two factors was measured by Cramer's association coefficient. Ideally, the value of the indicator should be 1 , in which case individuals see themselves in exactly the same way they think society sees them. The actual value of the indicator, 0.582 , shows that respondents think other members of society do not find the degree of development of their muscles to be exactly the same as they do. These doubts create exploitable business opportunities in terms of marketing. Due to the ideal body image promoted by consumer society, thin people would like to have a heavier build, and "fatter" people would like to be thinner; i.e. we encounter a social problem that exists only in the minds of consumers. The producers of dietary supplements offer solutions to all segments of the population for the real or perceived problems they may have. For a thin body shape, protein and muscleenhancing supplements are offered, and for those struggling with perceived or real excess weight, 'fat-burning' products are available.

In the research, the general attitudes of respondents towards dietary supplements were also assessed with the application of a five-point Likert scale ( 1 - strongly disagree, 5 - strongly agree). The mean of agreement with the given statements is presented in Figure 1. 
Figure 1 General perception of dietary supplements

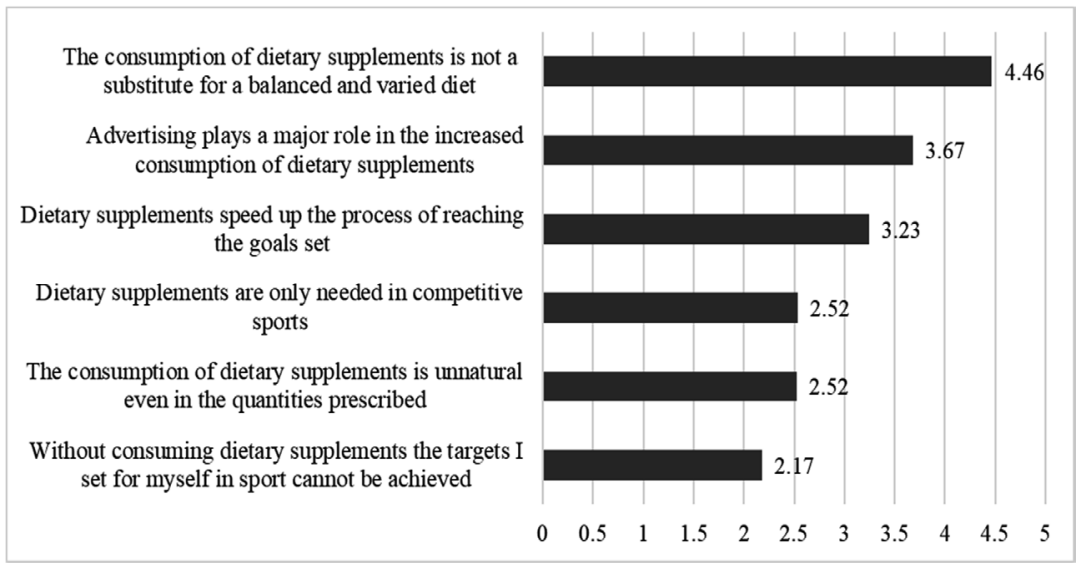

Note: Authors' calculations, 2020.

Figure 1 (above) shows that respondents generally disagree with the statement that the targets they define cannot be achieved without consuming dietary supplements (2.17), and also with the statement that the use of dietary supplements is only necessary in competitive sports (2.52). There is slightly stronger than average agreement with the statement that the use of dietary supplements speeds up the achievement of desired results (3.23). However, respondents do not accept that the consumption of dietary supplements is unnatural even in small quantities (2.52). Respondents confirm the importance of a balanced and varied diet (4.46), and the fact that dietary supplements cannot be a substitute for this. Results indicate that respondents find the claim that an increase in the consumption of dietary supplements can be attributed to advertising to be true (3.67). These findings can be interpreted as positive attitudes towards dietary supplements in terms of marketing. The results can be differentiated according to several viewpoints. A higher level of agreement can be observed in the following segments with the claims that: i) achieving defined goals is more difficult without the use of dietary supplements, and ii) consuming them is necessary to produce results faster: males; those who have been engaged in sports for a longer period of time; those with more muscles than average; and the overweight and obese, according to the classification based on BMI. In the segments mentioned above, the use of dietary supplements and corporate communication promoting these products is perceived more favorably than average. By calculating Kendall's coefficient of concordance (W), agreement 
with and the intensity of, the differences in the respondents' opinions can be determined. With respect to the 737 people surveyed, the calculated Kendall's W value among the respondents is $0.287(28.7 \%)$. The indicator draws attention to a below-average level of agreement; i.e. there are diverging opinions as regards the assessment of dietary supplements. Kendall's W value demonstrates that the population is far from homogeneous; indeed, it can be considered largely heterogeneous.

As concerns the means of promoting the sales of dietary supplements, communication by opinion leaders (coaches) and reference groups, and word-ofmouth advertising (fellow sportsmen) were found to be outstanding, surpassing the efficiency of traditional advertising. The number of mentions of the given sources of information are shown in Figure 2 below.

Figure 2 Sources of information about dietary supplements (number of mentions $/ n$ )

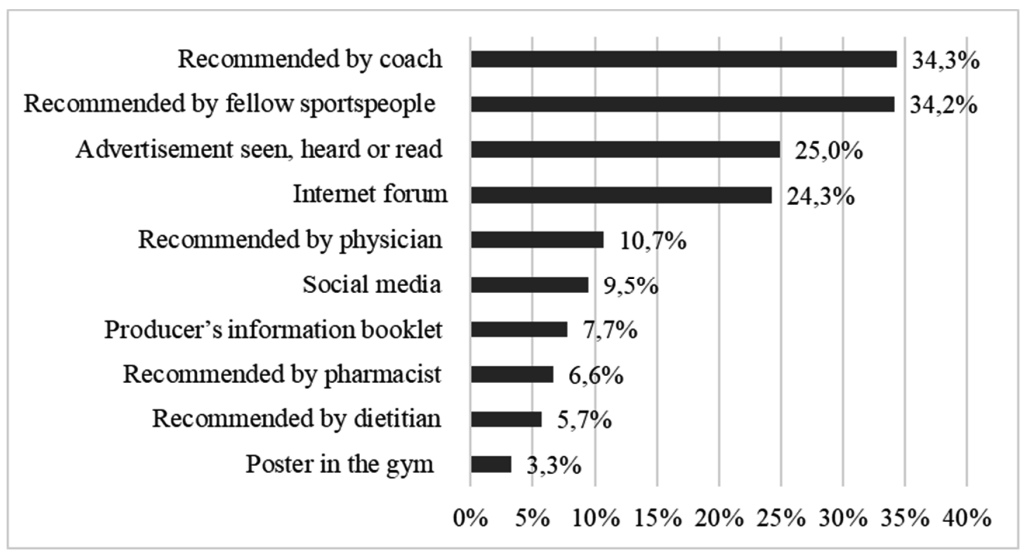

Note: The question was a multi-choice one, so the cumulative percentage exceeds $100 \%$. Authors' calculations, 2020 .

From Figure 2 (above) it can be concluded that non-traditional marketing communication tools may prove more effective in the market for dietary supplements than classical advertising. It is important to point out that it is not primarily from experts in the field that respondents acquire information - they use considerably less reliable sources. Guidance by physicians, pharmacists, and dietitians is outweighed by advice from coaches and fellow sportspeople, and more attention is paid to advertisements seen, heard, or read, or to information gathered from internet forums and social media than to information from experts. Figure 2. complements Parezanovic's results (2016) well. This situation 
may pose health risks in certain cases (such as with the consumption of fat burners, pre-workout formulas, and hormone regulators), and may give rise to justifiable calls for the regulation of communication regarding the product range; we are of the opinion that further examination needs to be carried out in relation to communication associated with this product range. Respondents in our survey generally purchase dietary supplements without asking people with medical expertise about their consumption, and the information they collect does not come from credible sources.

The consumption intensity of dietary supplements was also assessed in our survey. It is important to mention that different dietary supplements are recommended for consumption at different frequencies. Some of them are recommended as "cure-like" products for ad hoc consumption, or on a few occasions per week, while others may used up to several times a day. Consequently, objective and quantifiable consumption frequencies, applicable to all dietary supplements, cannot be established. In our view, respondents who reported the frequent, very frequent, daily, or a multiple times a day frequency of consumption of a particular dietary supplement should be regarded as regular and predictable consumers of the given product. Data from our research clearly shows that the dietary supplements consumed most frequently include (percentages in brackets refer to regular consumers)

- vitamins and minerals (75.7\%),

- proteins $(47.5 \%)$

- protein bars, cereal bars and energy bars $(45.2 \%)$

- products for joint support $(35.8 \%)$

- amino acids $(30.4 \%)$

- isotonic drinks (20.9\%).

Beside the product range listed above, pre-workout and post-workout formulas are also very popular, but it is hard to find any dietary supplements among those that are legally available for which effective demand was negligible. For the sake of comparison, the consumption intensity of illicit dietary supplements steroids - was also included in the study. Naturally, it cannot be taken for granted that respondents will admit the consumption of illicit drugs in a survey due to social pressure. Findings about the consumption of illicit dietary supplements steroids - among respondents in the study show that 22 people use them rarely or very rarely, four often, and four very often or on a daily basis.

The previous statement - that an above average positive attitude can be observed in specific segments: namely, males, respondents doing weight training, those with above-average muscles, and the overweight and obese according to the BMI classification - was also been found to be true as regards 
the consumption intensity of dietary supplements, although in a differentiated manner. Sympathy is also manifested in the conative component of the attitude, i.e. it is not restricted to the affective component only which means that the proportion of positive attitude and the consumption intensity are higher in these specific segments. The consumption intensity of dietary supplements can be differentiated by segments that include, but are not limited to, those identified in the list below.

- Men - with a few exceptions - consume dietary supplements at a higher intensity than women. Exceptions include protein bars, cereal bars, and energy bars, the consumption intensity of which is roughly the same for both genders; and the category of vitamins and minerals, where women have a $4 \%$ higher consumption intensity.

- Respondents classified into the overweight and obese BMI category consume the following products at a higher intensity: weight-control formulas, joint support products, proteins, hormone optimizers, and pre-workout and postworkout formulas. In their case, the reported consumption rate of illicit dietary supplements is as much as $2.6 \%$.

- The real target market of the producers of dietary supplements is represented by the segment of those doing weight training. These individuals consume dietary supplements in significantly higher proportions, almost without exception. Seventy per cent of the respondents use protein supplements at least at a frequent intensity, and $86 \%$ of them consume vitamins.

- The former purchase and consume practically everything they believe will help in their development, such as proteins, amino acids, joint support products, etc.

The consumption of dietary supplements can be investigated according to several criteria, such as gender, sports experience, BMI category, sport activity, etc. We do not think it is advisable to create a general, multivariate analysis because this would lead to an overly general result. For example, in relation to different sports activities, different dietary supplements are consumed by different groups according to age, gender, etc. This could not be shown in a general model. In our research, we thus used a better and more generally accepted method (K-means clustering) to classify the consumption of dietary supplements into different segments.

Since respondents in the study expressed quite different attitudes to the statements about dietary supplements, and moreover, this was also confirmed by the different data on consumption intensity in the different consumer groups, we examined what segments (clusters) respondents can be classified into based on their opinions, properties, and as regards consumption intensity. As Kendall's 
coefficient of concordance showed a below-average value (28.7\%), we created a larger number of segments based on additional segmentation criteria. Because of the great number of segmentation criteria (28 criteria were used to establish the segments), we give a shorter description of these criteria. Segmentation criteria included:

- questions examining the sports-related habits of the respondent sportspersons (e.g. How often do you play sport on a weekly basis? How long have you been doing it? Are you an amateur or professional sportsperson? Your category of sports?)

- questions examining the demographic and other descriptive characteristics of the interviewed sportspersons (e.g. gender, BMI, household income, etc.)

- attitudes towards dietary supplements. We used 5-point Likert scales and measured agreement with or rejection of the following statements: the use of dietary supplements means you can more quickly achieve goals in sports; their consumption is not natural; their consumption is not a substitute for a balanced, varied diet; their consumption is only necessary in professional sports; advertising plays a considerable role in the increase in consumption, etc.

- questions examining the consumption intensity of dietary supplements (e.g. how often do you consume proteins; amino acids; protein bars, cereal bars, energy bars; weight control formulas; vitamins, minerals; joint support products; creatine; muscle-building supplements; hormone optimizers; isotonic drinks, powders, gels; pre- and post-workout formulas or prohibited dietary supplements/steroids).

In the course of cluster analysis, the establishment of four groups (segments) proved to be a precise solution, with opinions that are clearly distinguishable. The main characteristics of the groups that were formed are described in the following paragraphs.

\section{Segment 1: athletes}

Sport is their life; members of this segment exercise five times a week on average. In this group, the proportion of individuals training up to several times a day is highest (21.1\%). $57.9 \%$ of the members of this segment claimed they were competitive athletes and undertook sports activities competitively. Members of this group consider themselves real sportspeople (94.7\%), and are typically of medium build, but their muscles and physique are developed to a well above average degree. They are genuinely critical of themselves; in their 
responses they reported a feeling of being slightly overweight. Not only do they show a positive attitude towards dietary supplements, but they also consume them in large quantities. Here, the consumption of all dietary supplements is higher than average. These individuals are also stable consumers. The high rate of consumption of prohibited dietary supplements/steroid is problematic $(21.1 \%$ consume significant amounts of steroids). The distribution of the consumption frequency of different dietary supplements in this segment of athletes is shown in Figure 3. These individuals are informed about dietary supplements by their coaches. The proportion of men in this segment amounts to $84.2 \%$. Within the group engaged in sports in regular basis, the size of this segment is $2.7 \%$.

Figure 3 Distribution of the consumption frequency of dietary supplements in the segment of athletes

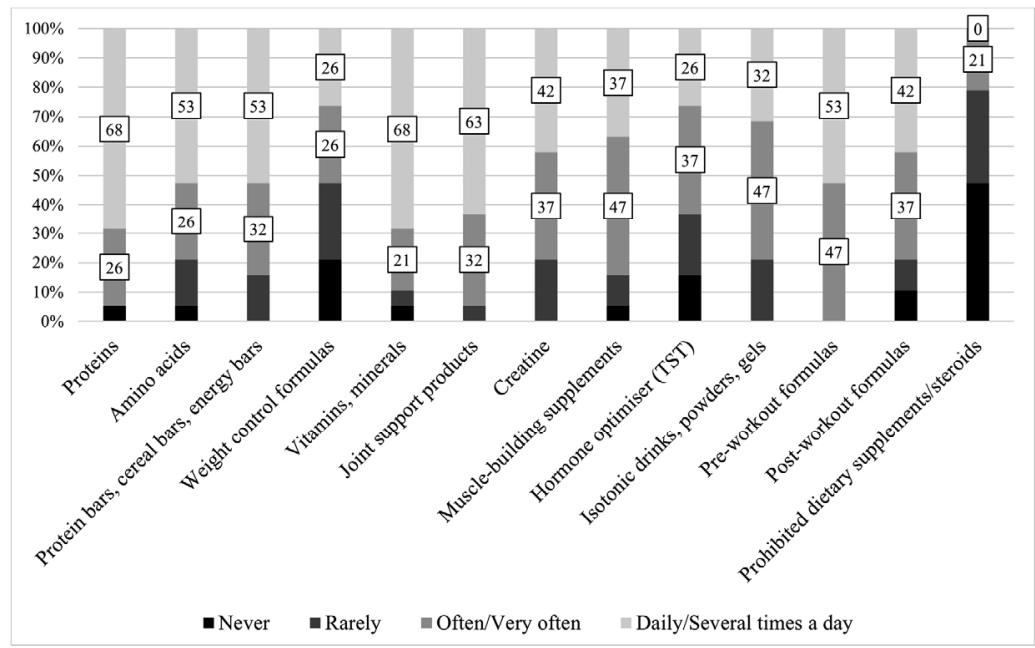

Note: Authors' calculations, 2020.

\section{Segment 2: recreational athletes}

Their lives are not centered around sport, but sport plays an important part. Members of this segment exercise two or three times a week (three times is typical). They are typically not involved in competitive sport, yet $66 \%$ of them claim to be sportspeople. Members of this segment are true, regular recreational athletes, and representatives of grassroots sports - the "mainstream" - with 
varied body shapes and degrees of muscular development. The proportion of women in this segment is high, reaching $47.6 \%$. The perception of dietary supplements is average and so is their consumption intensity. Members accept and consume the most popular dietary supplements, but apart from these, they have no special demand for this product range. A high degree of agreement can be observed concerning the statement that the increase in the consumption of dietary supplements is due to the marketing activities of producers. Dietary supplements are popular. The most common dietary supplements (e.g. proteins, protein bars, vitamins, minerals, and isotonic drinks) are consumed at a higher rate. The proportion of this segment within the population is $38.1 \%$. The distribution of the consumption frequency of different dietary supplements in the segment of athletes is shown in Figure 4.

Figure 4 Distribution of the consumption frequency of dietary supplements in the segment of recreational athletes

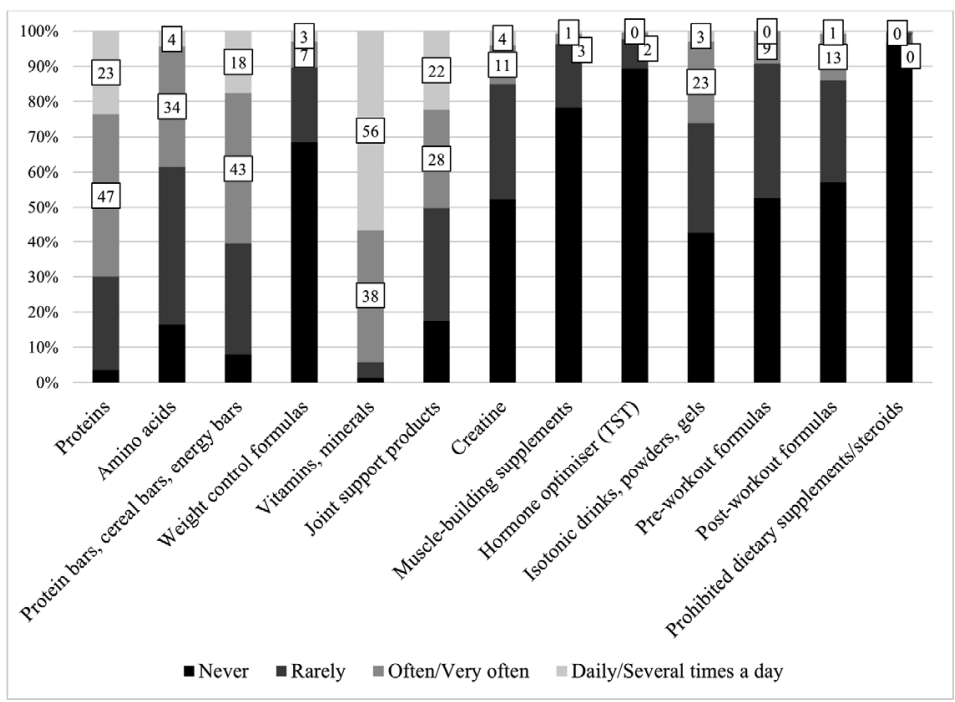

Note: Authors' calculations, 2020.

\section{Segment 3: average sportspeople}

These individuals are fond of sports, and doing sports is an important part of their lives. They exercise 4-5 times a week on average (five times is typical), but 
not usually on a competitive basis. Their aim is to keep in shape, and to achieve and maintain an optimum state of health. The proportion of competitive athletes in this segment is $25.0 \%$. They also consider themselves to be sportspeople (82.1\%); however, in their case, beside medium build, some incidence of being overweight can also be observed. $13.5 \%$ of the respondents define themselves as overweight, and $1.8 \%$ obese. Members of this segment tend to underestimate the incidence of obesity based on the BMI classification. Their muscles are much less developed than those of athletes, but they are in a significantly better shape than ordinary people. The group contains a high proportion of men $(75.9 \%)$, although women respondents are also well represented in this segment (24.1\%). Their attitude towards dietary supplements is positive to an above average degree, and consumption intensity is also high in the segment. The size of this segment within the population is $15.6 \%$. Consumption of dietary supplements is high (similar to segment 1 - athletes) but these individuals are not professional sportspeople. One considerable difference is that the consumption of prohibited dietary supplements/steroids is negligible. The distribution of the consumption frequency of different dietary supplements in the segment of average sportspeople is shown in Figure 5.

Figure 5 Distribution of the consumption frequency of dietary supplements in the segment of average sportspeople

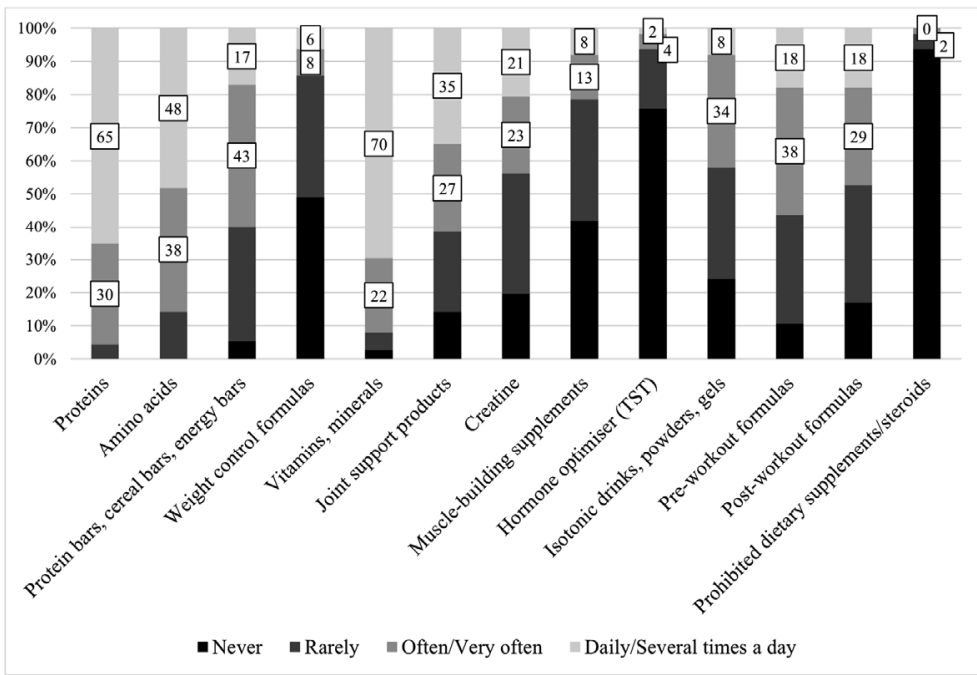

Note: Authors' calculations, 2020. 


\section{Segment 4: those who refuse dietary supplements}

Figure 6 Distribution of the consumption frequency of dietary supplements in the segment those who refuse dietary supplements

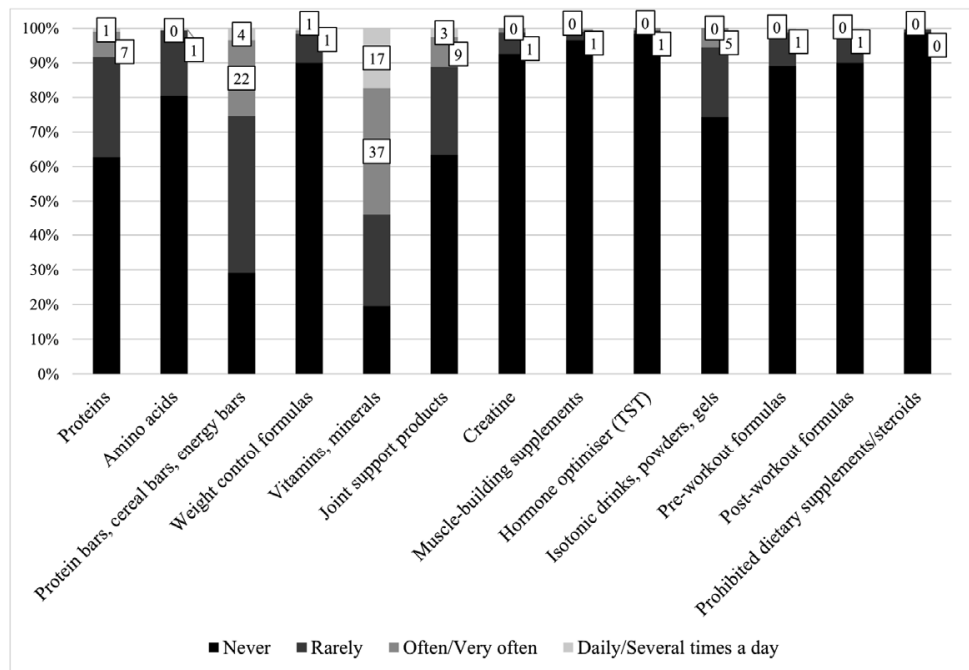

Note: Authors' calculations, 2020.

These individuals support a natural approach to health; in a narrow sense, they are "natural" sportspeople. They exercise twice or three times a week on average, but only once a week is not rare for this segment (22.1\%). Consequently, 50.3\% of the members of this segment do not consider themselves to be sportspeople. They are people for whom sport is much more a form of pressure than fun. $18.4 \%$ of the respondents consider themselves overweight or obese, with $52.2 \%$ believing they have average muscles As regards body build, their judgements of themselves are favorably biased compared to their BMI classification, since the proportion of overweight and obese respondents in this segment is $40.1 \%$. They express significant doubt about dietary supplements, and their attitudes are considerably more negative about them than positive. They believe that there is really no need to consume dietary supplements when doing sports, and that such need is generated by advertising. They are even skeptical about more generally accepted vitamins and minerals; $19.6 \%$ of them never consume such dietary supplements. The combined proportion of responses of never, very rarely, and rarely responses is $46.2 \%$. This is the segment in which the proportion of women 
is highest (57.7\%). Within the population, the size of this segment is $43.6 \%$. The distribution of the consumption frequency of different dietary supplements in the segment of those who on average refuse dietary supplements is shown in Figure 6 .

The accuracy of the distribution can be confirmed by the fact that $96.5 \%$ of all respondents could be properly classified.

\section{CONCLUSIONS}

The findings of our research clearly indicate that the group of people engaging in sports on a regular basis is far from homogeneous (for example, according to their consumption of dietary supplements), even though they exercise voluntarily. In our research, we identified four different segments. Groups can be unambiguously identified and have a variable nature. This segmentation indicates that there are two segments ("athletes" and "average sportspeople") who have a strong, positive attitude towards dietary supplements and who constitute the stable consumers of the product range. The segment "recreational athletes" expands the range of potential consumers. This is the "mainstream" of the market. The total size of the three above-mentioned segments is $56.4 \%$. Only one segment ("those who refuse dietary supplements") expresses strong doubts about dietary supplements, and their attitudes are considerably more negative than positive. Moreover, the situation is a lot more nuanced than this. There are some other factors that influence consumers' buying behavior.

Respondents' dissatisfaction with their own body shape is further intensified by the cult of the body emphasized in our present consumer society, by the ideals of an unrealistic body shape (too thin, too muscular) presented by corporate marketing communication, and by powerful advertising. The same holds true for the perceptions of our respondents. However, producers and distributors, beside drawing consumers' attention to and emphasizing the flaws with their body shape (too thin, overweight, not muscular enough), offer solutions to problems both perceived and real. They provide products for dealing with all kinds of problems - e.g. they offer weight gain products for people of a thin build, pre-workout formulas for those who intend to train hard, protein for those wishing for more muscle mass, fat burners for the obese, etc. This is a highly profitable industry, which builds on individuals' lack of self-confidence, doubts, and fears. People who are uncertain about their own body shape are potential customers of dietary supplements. The more uncertain the consumer is, the more favorable the situation is for the producer, since such consumers 
are more likely to make a purchase - typically, an emotional problem-solving purchase. In terms of marketing, the formula is simple; draw consumers' attention to their imperfect body shape, highlight problems, and, at the same time, offer solutions to the given problems. Consumer protection policy is typically meant to protect such consumer groups from corporate marketing activities by means of active and passive methods of consumer protection. However, at present, regulation of the communication of this product range is rather weak, and producers and distributors of dietary supplements do not have to comply with substantial restrictions. Based on the results of our research, we do not intend to take a stand about the need for stricter active legislation; the latter will not be the solution in the long term, although it may yield results in the short run. Passive approaches may be more effective at strengthening consumer awareness in the long term. In our view, one serious problem is that respondents collect information about dietary supplements primarily from laypeople, by way of word of mouth advertising, and not from health experts (physicians, pharmacists, or dietitians). Our previous research studies have pointed out that the cognitive level of consumer awareness is extremely low in Hungary; consumers simply have little knowledge about foods, or consumer rights. Individuals like to believe that they are conscious about such things, but except for a very small segment, they are not (Szücs, 2019). Respondents purchase dietary supplements because their coach advised them to do so, or because they allegedly worked for a fellow sportsperson who trained well and rapidly gained muscle. For example, respondents purchase protein powders and consume three shakes a day without knowing the exact protein demand of their bodies (the word 'protein' in the previous sentence could be replaced with any other dietary supplement). As regards acquiring information, respondents can by no means be considered conscious; thus we believe that producers should be under stricter obligations to provide more accurate information.

\section{REFERENCES}

Bauer, Béla - Pillók, Péter - Ruff, Tamás - Szabó, Andrea - Szanyi F., Eleonóra - Székely, Levente (2017) Magyar Ifjúság Kutatás 2016. Az Ifjúságkutatás első eredményei. Ezek a mai magyar fiatalok!, Társadalomkutató Kft., http:// real.mtak.hu/119224/1/magyar_ifjusag_2016_2_A4.pdf, p.52, Last access: 09.02.2021

Bíró, Lajos - Szeitz-Szabó, Mária - Bíró, György - Sali, Judit (2011) Dietary Survey in Hungary, 2009. Part II: Vitamins, Macro- and Microelements, Food 
Supplements and Food Allergy. Acta Alimentaria. Vol.40, No.2, DOI: 10.1556/ AAlim.40.2011.2.14, p. 301-312.

Boros, Péter - Fehér, Orsolya - Kajári, Karolina (2012) Élelmiszerfogyasztói attitűdök vizsgálata a funkcionális élelmiszerek és az étrend-kiegészítő termékek kontextusában. Deturope. The Central European Journal Of Regional Development And Tourism Vol.4 Issue 1 2012, ISSN 1821-2506, http://www.deturope.eu/img/upload/content_93153079.pdf, p. 64 - 75. Last access: 09.02.2021

Central Statistical Office, CSO (2015a) Európai lakossági egészségfelmérés, 2014. Statisztikai tükör, 2015/29, 2015. április 30., https://www.ksh.hu/docs/ hun/xftp/stattukor/elef14.pdf, p.9., Last access: 09.02.2021

Central Statistical Office, CSO (2015b) Európai lakossági egészségfelmérés, 2014. Táblázatok, Sporttevékenység, https://www.ksh.hu/elef/archiv/2014/ tablak/elef_osszefoglalo_adatok_09.xls, Last access: 09.02.2021

Central Statistical Office, CSO (2015c) Európai lakossági egészségfelmérés, 2014. Táblázatok, Testtömeg-index, https://www.ksh.hu/elef/archiv/2014/ tablak/elef_osszefoglalo_adatok_10.xls, Last access: 09.02.2021

Dwyer, Johanna. T. - Coates, Paul. M. - Smith, Michael. J. (2018) Dietary Supplements: Regulatory Challenges and Research Resources, Nutrients, Vol. 10 No.1, 41., doi: 10.3390/nu10010041, https://www.ncbi.nlm.nih.gov/pmc/ articles/PMC5793269/, p. 24, Last access: 09.02.2021

Eurostat (2019) Persons performing physical activity outside working time by duration in a typical week, educational attainment level, sex and age. http://bit. ly/eurostat_2017_persons_performing_physical_activity_outside_working _ time, Last update: 18.12.2019, Last access: 22.01 .2020

Gilbert, Linda (2000) Marketing functional foods. How to reach your target audience? The Journal of Agrobiotechnology Management \& Economics, Vol. 3, No.1, p. 20-38.

Keller, Veronika - Dernóczy-Polyák, Adrienn (2017) Fiatalok sportolási szokásai generációs megközelítésben, In. Kautz Konferencia 2017 „,Sport - Gazdaság - Turizmus", https://kgk.sze.hu/images/dokumentumok/ kautzkiadvany2017/Keller_Dernoczy_Kautz_2017.pdf, pdf, p. 9, Last access: 09.02.2021

Kruseman, Maaike - Gremeaux, Vincent (2020) Optimizing nutritional supplementation in sports, Revue Médicale Suisse, 2020 Aug 05; Vol. 16 (701), p. 1401-1404.

Lubowiecki-Vikuk, Adrian - Król-Zielińska, Magdalena - Kantanista, Adam (2019) Consumption of dietary supplements to support weight reduction in adults according to sociodemographic background, body mass index, waisthip ratio, body fat and physical activity. Journal of Health, Population and 
Nutrition, https://jhpn.biomedcentral.com/articles/10.1186/s41043-019-01913, 38:31, Last access: 09.02.2021

Lugasi, Andrea (2014) Az étrend-kiegészítők kockázati tényezői, Magyar Tudomány, http://www.matud.iif.hu/2014/11/11.htm, Last access: 09.02.2021 Magkos, Faidon - Yannakoulia, Mary (2003) Methodology of dietary assessment in athletes: concepts and pitfalls. Current opinion in clinical nutrition and metabolic care, Vol. 6 (5), pp. 539-49

Németh, Nikolett - Lehota, József - Gyenge, Balázs (2016) Fogyasztói magatartás vizsgálata az étrend-kiegészítők piacán, EMOK - XXII. Országos Konferencia - Hitelesség és értékorientáció a marketingben, https://emok. hu/tanulmany-kereso/d489:fogyasztoi-magatartas-vizsgalata-az-etrendkiegeszitok-piacan/pdf, p. 426 - 434, Last access: 09.02.2021

Parezanovic, Gordana Svonja (2016) Dietary supplement use among adolescents. Macedonian Pharmaceutical Bulletin, Vol. 62, p. 369-370

Poulios, Athanasios - Georgakouli, Kalliopi - Draganidis, Dimitrios - Deli, Chariklia K. - Tsimeas, Panagiotis D. - Chatzinikolaou, Athanasios Papanikolaou, Konstantinos - Batrakoulis, Alexios-Mohr, Magni-Jamurtas, Athanasios Z. - Fatouros, Ioannis G. (2019) Protein-Based Supplementation to Enhance Recovery in Team Sports: What is the Evidence?, Journal of Sports Science and Medicine, Vol. 18, No. 3, p. 523-536.

Szücs, Róbert Sándor (2019) A fogyasztói tudatosság marketing és fogyasztóvédelmi szempontú vizsgálata. Tézisszerü bevezetővel ellátott cikkgyűjtemény a habilitáció elnyerésére, Debreceni Egyetem, Ihrig Károly Gazdálkodás- és Szervezéstudományok Doktori Iskola, p. 54

WHO (2011) Global Strategy on Diet, Physical Activity and Health, Information sheet: global recommendations on physical activity for health 18 - 64 years old, https://www.who.int/dietphysicalactivity/physical-activity-recommendations18-64years.pdf, p.1, Last access: 09.02.2021 